\title{
Should primary aldosteronism be diagnosed among normotensive subjects during general health check-up and/or at general outpatient clinics?
}

\author{
Tetsuo Nishikawa and Masao Omura \\ Hypertension Research (2011) 34, 47-48; doi:10.1038/hr.2010.202; published online 21 October 2010
}

$\mathrm{T}^{\mathrm{s}}$ he accepted prevalence worldwide of primary aldosteronism (PA) in unselected patients with hypertension was considered to be low in the past, perhaps about $2 \%$ or even $<1 \%{ }^{1}$ However, there have recently been reports suggesting higher values suggesting a prevalence of up to $10-15 \%$ among patients with hypertension. ${ }^{2,3}$ Nevertheless, there have always been wide variations in the reported prevalence of hyperaldosteronism. When Conn first described the syndrome, he estimated that about $20 \%$ of hypertensives would have an adrenal adenoma, ${ }^{4}$ whereas most experts previously described PA in $<1 \%$ of patients with mildto-moderate essential hypertension and had assumed hypokalemia was only a selective marker for differentiating PA among hypertensives. ${ }^{5-11}$ Recent cross-sectional studies reported PA in $>10 \%$ of hypertensive patients, in both general and specialty settings. ${ }^{12-18}$

Moreover, the results of recent screening of hypertensive patients in Japan using the simultaneous measurements of the plasma aldosterone concentration (PAC) and plasma renin activity (PRA) or the aldosterone-renin ratio (ARR) have shown that PA is observed in $3.3-10 \%$ of hypertensive patients and is the most frequent cause of secondary hypertension. ${ }^{19-23}$ However, the prevalence of this disease among normotensive and mildly hypertensive patients has not yet been estimated.

In this issue, Ito et al. ${ }^{24}$ provides data showing that the prevalence of PA as could be assessed in his study was at least $6.8 \%$ in

Dr T Nishikawa and M Omura are at the Division of Endocrinology and Metabolism, Department of Medicine, Yokohama Rosai Hospital, 3211 Kozukue-cho, Kohoku-ku, Yokohama City, Kanagawa 222-0036, Japan. E-mail: tetsuon@yokohamah.rofuku.go.jp prehypertensive patients, $3.3 \%$ in stage 1 hypertensive patients, and $3.1 \%$ in stage 2 hypertensive patients. They screened a total of 292 adult subjects with hypertension or prehypertension based on a PAC (ng per 100ml) to PRA ( $\mathrm{ng} \mathrm{ml}^{-1} \mathrm{hr}^{-1}$ ) ratio (ARR) above 20 and confirmed by captopril suppression test. Ito's study suggests a high prevalence of PA among prehypertensive and stage 1 hypertensive Japanese patients. ${ }^{24}$ They concluded that significant numbers of prehypertensive individuals may have subclinical forms of this disease.

There have been several case reports, describing PA without hypertension, ${ }^{25-31}$ although the reason for the absence of hypertension has not been clarified in any of the cases of normotensive PA reported. It is suggested that a short duration of hyperaldosteronemia could explain normotension in those patients. Thus, it is recommended that we should note the presence of normotensive PA at the general health check-up or general outpatient clinics, in order to prevent cardiovascular events, induced by hyperaldosteronemia, which may easily occur in the near future. It is well known that PA is a disease caused by autonomic hypersecretion of aldosterone because of the adrenocortical lesions, associated with increased urinary potassium excretion, and organ disorders (cerebral hemorrhage, cerebral infarction, myocardial infarction, cardiomegaly, arrhythmia, renal insufficiency and so on.) due to excessive aldosterone. ${ }^{32-34}$ When the patient with normotensive PA can physically tolerate and wishes to undergo surgical treatment, determination of whether aldosterone hypersecretion is bilateral or unilateral, and, if unilateral, which adrenal gland is responsible by adrenal venous sampling (AVS), is also necessary, like as the cases with hypertensive PA. ${ }^{35-37}$ Thus, it is suggested that we need to enthusiastically treat normotensive PA after detecting the laterality of adrenal lesions by AVS, although we should statistically analyze whether or not surgical treatment for the subclinical form of PA, such as nermotensive PA induces better prognosis for long periods of life.

In conclusion, it is suggested from the data presented by Ito et al. ${ }^{24}$ that the prevalence of $\mathrm{PA}$ is at least $6.8 \%$ in prehypertensive patients. Thus, prehypertensive individuals should be screened for the subclinical form of PA in order initiate early diagnosis and treatment to prevent future risks.

1 Connell JM. Is there an epidemic of primary hyperaldosteronism? J Hum Hypertens 2002; 16: 151-152.

2 Gordon RD, Stowasser M, Tunny TJ, Klemm SA, Rutherford JC. High incidence of primary hyperaldosteronism in 199 patients referred with hypertension. Clin Exp Pharmacol Physiol 1994; 21: 315-318.

3 Lim PO, Dow E, Brennan G, Jung RT, MacDonald TM. High prevalence of primary hyperaldosteronism in the Tayside hypertension clinic population. J Hum Hypertens 2000; 14: 311-315.

4 Sherwin RP, Conn JW. Present status of pathology of adrenal gland in hypertension. Am J Surg 1964; 107: 136-143.

5 Fishman LM, Kuchel O, Liddle GW, Michelakis AM, Gordon RD, Chick WT. Incidence of primary aldosteronism uncomplicated 'essential' hypertension. A prospective study with elevated aldosterone secretion and suppressed plasma renin activity used as diagnostic criteria. JAMA 1968; 205: 497-502.

6 Caplan RH, Strutt PJ, Wickus GG. Subclinical hormone secretion by incidentally discovered adrenal masses. Arch Surg 1994; 129: 291-296.

7 Andersen GS, Toftdahl DB, Lund JO, Strandgaard S, Nielsen PE. The incidence rate of phaeochromocytoma and Conn's syndrome in Denmark, 1977-1981. J Hum Hypertens 1988; 2: 187-189.

8 Berglund G, Andersson O, Wilhelmsen L. Prevalence of primary and secondary hypertension: studies in a random population sample. BMJ 1976; 2: 554-556. 
9 Streeten DH, Tomycz N, Anderson GH. Reliability of screening methods for the diagnosis of primary aldosteronism. Am J Med 1979; 67: 403-413.

10 Tucker RM, Labarthe DR. Frequency of surgical treatment for hypertension in adults at the Mayo Clinic from 1973 through 1975. Mayo Clin Proc 1977; 52: 549-555.

11 Sinclair AM, Isles CG, Brown I, Cameron H, Murray GD, Robertson JW. Secondary hypertension in a blood pressure clinic. Arch Intern Med 1987; 147: 1289-1293.

12 Schwartz GL, Turner ST. Screening for primary aldosteronism in essential hypertension: diagnostic accuracy of the ratio of plasma aldosterone concentration to plasma renin activity. Clin Chem 2005; 51: 386-394.

13 Gordon RD, Stowasser M, Tunny TJ, Klemm SA, Rutherford JC. High incidence of primary aldosteronism in 199 patients referred with hypertension. Clin Exp Pharmacol Physiol 1994; 21: 315-318.

14 Loh KC, Koay ES, Khaw MC, Emmanuel SC, Young Jr WF. Prevalence of primary aldosteronism among Asian hypertensive patients in Singapore. J Clin Endocrinol Metab 2000; 85: 2854-2859.

15 Fardella CE, Mosso L, Gomez-Sanchez C, Cortes P, Soto J, Gomez L, Pinto M, Huete A, Oestreicher E, Foradori A, Montero J. Primary hyperaldosteronism in essential hypertensives: prevalence, biochemical profile, and molecular biology. J Clin Endocrinol Metab 2000; 855: 1863-1867.

16 Lim PO, Dow E, Brennan G, Jung RT, MacDonald TM. High prevalence of primary aldosteronism in the Tayside hypertension clinic population. J Hum Hypertens 2000; 14: 311-315.

17 Mosso L, Carvajal C, Gonzalez A, Barraza A, Avila F, Montero J, Huete A, Gederlini A, Fardella CE. Primary aldosteronism and hypertensive disease. Hypertension 2003; 42: 161-165.

18 Hamlet SM, Tunny TJ, Woodland E, Gordon RD. Is aldosterone/renin ratio useful to screen a hypertensive population for primary aldosteronism? Clin Exp Pharmacol Physiol 1985; 12: 249-252.

19 Nishikawa T, Omura M. Clinical characteristics of primary aldosteronism: its prevalence and comparative studies on various causes of primary aldosteronism in
Yokohama Roai Hospital. Biomed Phamacother 2000; 54: 83-85.

20 Omura M, Saito J, Yamaguchi K, Kakuta Y, Nishikawa T. Prospective study on the prevalence of secondary hypertension among hypertensive patients visiting a general outpatient clinic in Japan. Hypertens Res 2004; 27: 193-202.

21 Naruse M, Tanaka T, Otani S, Ogwa J, Tanabe M, Ishizuka N. PHAS-J Study Group-A study on the frequency of primary aldosteronism in hypertensive patients in Japan using the network of the National Hospital Organization (NHO). Folia Endocrinologica Japonica 2009; 85: 246S.

22 Komiya I, Yamada T, Takasu N, Asawa T, Akamine H, Yagi $N$, Nagasawa $Y$, Ohtsuka $H$, Miyahara $Y$, Sakai H, Sato A, Aizawa T. An abnormal sodium metabolism in Japanese patients with essential hypertension, judged by serum sodium distribution, renal function and renin-aldosterone system. J Hypertens 1997; 15: 65-72.

23 Committee for the Preparation of Guidelines for the Treatment of Hypertension, Japanese Society of Hypertension. Guidelines for the Treatment of Hypertension 2009. Life Science Publishing: Tokyo, 2009.

24 Ito Y, Takeda R, Karashima S, Yamamoto Y, Yoneda T, Takeda Y. Prevalence of primary aldosteronism among prehypertensive and stage 1 hypertensive subjects. Hypertens Res 2011; 34: 98-102

25 Snow MH, Nicol P, Wilkinson R, Hall R, Johnston ID, Hacking PM, Rolland C. Normotensive primary aldosteronism. BMJ 1976; 1: 1125-1126.

26 Zipser RD, Speckart PF. 'Normotensive' primary aldosteronism. Ann Intern Med 1978; 88: 655-656.

27 Shiroto H, Ando H, Ebitani I, Hara M, Numazawa K, Kawamura S, Sasaki H. Normotensive primary aldosteronism. Am J Med 1980; 69: 603-606.

28 Kono $\mathrm{T}$, Ikeda $\mathrm{F}$, Oseko F, Imura $\mathrm{H}$, Tanimura $\mathrm{H}$. Normotensive primary aldosteronism: report of a case. J Clin Endocrinol Metab 1981; 52: 1009-1013.

29 Matsunaga M, Hara A, Song TS, Hashimoto M, Tamori S, Ogawa K, Morimoto K, Pak CH, Kawai C, Yoshida O. Asymptomatic normotensive primary aldoster-onism. Case report. Hypertension 1983; 5: 240-243.
30 Ogihara T, Maruyama A, Hata T, Naka T, Imanaka S, Kumahara Y, Matsumiya K, Ihara H, Koide T, Sagawa S, Saruta T. A zcase of normoreninemic normotensive primary aidosteronism associated with nephrocalcinosis. Nippon Naikagakkai Zatsushi 1982; 71: 77-82.

31 Nishimiya T, Kikuchi K, Oimatsu H, Ota S, Nakamura Y, Shimamoto K, limura $\mathrm{O}$. A case of normotensive primary aldosteronism-comparison with 13 previously experienced cases with hypertension. Endocrinol Jpn 1984; 31: 159-164.

32 Takeda R, Matsubara T, Miyamori I, Hatakeyama H, Morise T. Vascular complications in patients with aldosterone producing adenoma in Japan: comparative study with essential hypertension. J Endocrinol Invest 1995; 18: 370-373.

33 Nishimura M, Uzu T, Fujii T, Kuroda S, Nakamura S, Inenaga T, Kimura G. Cardiovascular complications in patients with primary aldosteronism. Am J Kidney Dis 1999; 33: 261-266.

34 Tanabe A, Naruse M, Naruse K, Hase M, Yoshimoto T, Tanaka M, Seki T, Demura R, Demura H. Left ventricular hypertrophy is more prominent in patients with primary aldosteronism than in patients with other types of secondary hypertension. Hypertens Res 1997; 20: 85-90.

35 Omura M, Sasano H, Fujiwara T, Yamaguchi K, Nshikawa T. Unique cases of unilateral hyperaldosteronism due to multiple adrenocortical micronodules, which can only be detected by selected adrenal venous sampling. Metabolism 2002; 51: 350-355.

36 Omura M, Sasano H, Saito J, Yamaguchi K, Kakuta Y, Nishikawa T. Clinical characteristics of aldosteroneproducing microadenoma, macroadenoma, and idiopathic hyperaldosteronism in 93 patients with primary aldosteronism. Hypertens Res 2006; 29: 883-889.

37 Satoh F, Abe T, Tanemoto M, Nakamura M, Abe M, Uruno A, Morimoto R, Sato A, Takase K, Ishidoya S, Arai Y, Suzuki T, Sasano H, Ishibashi T, Ito S. Localization of aldosterone-producing adrenocortical adenomas: significance of adrenal venous sampling. Hypertens Res 2007; 30: 1083-1095. 